\title{
Hong Kong College of Physicians Position Statement and Recommendations on the 2017 American College of Cardiology/ American Heart Association and 2018 European Society of Cardiology/European Society of Hypertension Guidelines for the Management of Arterial Hypertension
}

\author{
KK Chan *, CC Szeto, Christopher CM Lum, PW Ng, Alice PS Kong, KP Lau, Jenny YY Leung, SL Lui,
} KL Mo, Francis CK Mok, Vincent CT Mok, Bryan PY Yan, Philip KT Li *

\section{A B S T R A C T}

The American College of Cardiology/American Heart Association released guidelines for the prevention, detection, evaluation, and management of high blood pressure (BP) in adults in 2017. In 2018, the European Society of Cardiology (ESC)/ European Society of Hypertension (ESH) published new guidelines for the management of arterial hypertension. Despite the many similarities between these two guidelines, there are also major differences in the guidelines in terms of diagnosis and treatment of hypertension. A working group of the Hong Kong College of Physicians (HKCP) convened and conducted a focused discussion on important issues of public interest, including classification of BP, BP measurement, thresholds for initiation of antihypertensive medications, BP treatment targets, and treatment strategies. The HKCP concurs with the $2018 \mathrm{ESC} / \mathrm{ESH}$ guideline on BP classification, which defines hypertension as office systolic BP $\geq 140 \mathrm{~mm} \mathrm{Hg}$ and/or diastolic $\mathrm{BP} \geq 90 \mathrm{~mm} \mathrm{Hg}$. The HKCP also acknowledges the growing evidence of home BP monitoring and ambulatory BP monitoring in the diagnosis and monitoring of hypertension and endorses the wider use of both methods. The HKCP also supports the direction of a risk-based approach for initiation of antihypertensive medications and the specification of a treatment target range for both systolic and diastolic BP with consideration of different age-groups and specific disease subgroups. Non-pharmacological interventions are crucial, both at the societal and individual patient levels. The recent guideline publications provide good opportunities to increase public awareness of hypertension and encourage lifestyle modifications among the local population.

Hong Kong Med J 2020;26:432-7

https://doi.org/10.12809/hkmj198330

${ }^{1}$ KK Chan *, FHKCP, FHKAM (Medicine)

${ }^{2}$ CC Szeto, FHKCP, FHKAM (Medicine)

${ }^{3}$ CCM Lum, FHKCP, FHKAM (Medicine)

${ }^{4}$ PW Ng, FHKCP, FHKAM (Medicine)

${ }^{2}$ APS Kong, MD, FHKCP, FHKAM (Medicine)

${ }^{5}$ KP Lau, FHKCP, FHKAM (Medicine)

JYY Leung, FHKCP, FHKAM (Medicine)

${ }^{7}$ SL Lui, MD (HK), FHKAM (Medicine)

${ }^{1} \mathrm{KL}$ Mo, FHKCP, FHKAM (Medicine)

${ }^{8}$ FCK Mok, FHKCP, FHKAM (Medicine)

${ }^{2}$ VCT Mok, FHKCP, FHKAM (Medicine)

${ }^{2}$ BPY Yan, FHKCP, FHKAM (Medicine)

${ }^{2}$ PKT Li *, FHKCP, FHKAM (Medicine)

Department of Medicine, Pamela Youde Nethersole Eastern Hospital, Hong Kong

Department of Medicine and Therapeutics, The Chinese University of Hong Kong, Prince of Wales Hospital, Hong Kong

Department of Medicine and Geriatrics, Shatin Hospital, Hong Kong

${ }^{4}$ Private Practice, Hong Kong

${ }^{5}$ Department of Medicine, North District Hospital, Hong Kong

${ }^{6}$ Department of Medicine, Ruttonjee Hospital, Hong Kong

Department of Medicine, Tung Wah Hospital, Hong Kong

Department of Medicine and Geriatrics, Tuen Mun Hospital, Hong Kong

* Corresponding authors: chankk5@ha.org.hk; philipli@cuhk.edu.hk

\section{Introduction}

In 2017, the American College of Cardiology (ACC)/ American Heart Association (AHA) released a guideline for the prevention, detection, evaluation, and management of high blood pressure (BP) in adults. ${ }^{1}$ This guideline was a collaborative effort by 11 organisations that updated the JNC7 (Seventh
Report of the Joint National Committee on Prevention, Detection, Evaluation and Treatment of High Blood Pressure) in 2003. ${ }^{2}$ In 2018, the European Society of Cardiology (ESC)/European Society of Hypertension (ESH) published a new guideline for the management of arterial hypertension. ${ }^{3}$ Both the European and American guidelines provide comprehensive 
information for the clinical and public-health practice communities on high BP management. There are many similarities between these two sets of guidelines: both emphasise the importance of accurate BP measurement and encourage out-of-office BP measurement for confirmation of hypertension diagnosis. Both sets of guidelines also recommend cardiovascular disease risk estimation for risk stratification and a core strategy of non-pharmacological lifestyle interventions and drug treatment, including combination drug therapy. Despite the many similarities between these two guidelines, the guidelines also have major differences in terms of diagnosis and treatment of hypertension.

Hypertension is prevalent in Hong Kong. In a population health survey in 2014/15 conducted by Department of Health, ${ }^{4}$ the prevalence of hypertension (systolic BP $[\mathrm{SBP}] \geq 140 \mathrm{~mm} \mathrm{Hg}$ and/or diastolic BP [DBP] $\geq 90 \mathrm{~mm} \mathrm{Hg}$ ) was $27.7 \%$ among persons aged 15 to 84 years, with $47.5 \%$ of them having been undiagnosed before the survey. The prevalence of hypertension increased steadily with age, from $4.5 \%$ among those aged 15 to 24 years to $64.8 \%$ among those aged 65 to 84 years.

A working group of the Hong Kong College of Physicians (HKCP) convened and conducted a focused discussion on important issues of public interest pertaining to these two guidelines. This document formulates the HKCP's views on the following issues: (1) classification of BP; (2) BP measurement; (3) thresholds for initiation of antihypertensive medications; (4) BP treatment targets; and (5) treatment strategies.

\section{Classification of blood pressure}

The 2018 ESC/ESH guideline defines hypertension as office SBP $\geq 140 \mathrm{~mm} \mathrm{Hg}$ and/or DBP $\geq 90 \mathrm{~mm} \mathrm{Hg}$ (Table $1^{3}$ ). This definition remains unchanged from the previous $2013 \mathrm{ESC} / \mathrm{ESH}$ guideline. ${ }^{5}$ However, the 2017 ACC/AHA guideline contains a new BP classification that proposes a lower threshold to define hypertension (SBP $\geq 130 \mathrm{~mm} \mathrm{Hg}$ and/or DBP $\geq 80 \mathrm{~mm} \mathrm{Hg}$ ). The same guideline defines normal $\mathrm{BP}$ as $<120 / 80 \mathrm{~mm} \mathrm{Hg}$ and elevated $\mathrm{BP}$ as 120 to $129 \mathrm{~mm} \mathrm{Hg}$ SBP and $<80 \mathrm{~mm} \mathrm{Hg}$ DBP.

The Systolic Blood Pressure Intervention Trial is an important trial that significantly influenced the recommendations of the 2017 ACC/AHA guidelines. ${ }^{6}$ The method used for office BP measurement in the Systolic Blood Pressure Intervention Trial was unattended automatic measurement, in which automated multiple BP readings in a doctor's office are obtained with the patient seated alone and unobserved. This method has not been used in any previous randomised controlled trials that provide an evidentiary basis for the treatment of hypertension. The relationship between conventional office BP measurement and

\section{根據2017年美國心臟病學院和美國心臟協會以 及2018年歐洲心臟學會和歐洲高血壓學會的高 血壓管理指南, 香港內科醫學院制定的有關立場 聲明和建議}

陳國強、司徒卓俊、林楚明、吳炳榮、江碧珊、劉錦標、 梁彥欣、雷聲亮、毛家亮、莫俊強、甄秉言、李錦滔

美國心臟病學院和美國心藏協會於 2017 年發布成人高血壓的預防、檢 測、評估和管理指南。歐洲心臟學會和歐洲高血壓學會（ESC/ESH） 亦於2018年發佈最新動脈高血壓治療指南。儘管這兩個指南之間有 很多相似之處, 但在高血壓的診斷和治療方面, 指南也存在重大差 異。香港內科醫學院工作小組召集並就公共利益的重要問題進行重點 討論, 包括血壓分類、血壓測量、降壓藥物起始閾值、血壓管理治療 目標以及治療策略。學院認同2018年ESC/ESH血壓分類指南, 該指 南將高血壓定義為診間收縮壓 $\geq 140 \mathrm{~mm} \mathrm{Hg}$ 和/或舒張壓 $\geq 90 \mathrm{~mm} \mathrm{Hg}$ 學院亦確認越來越多的證據表明家居及門診血壓監測對診斷和監測高 血壓的作用, 並支持兩種方法的廣泛使用。學院還支持以風險為基礎 的抗高血壓藥物療法的方向, 以及考慮不同年齡組別和特定疾病亞組 的收縮壓和舒張壓治療目標範圍的規範。無論是在社會還是個人患者 層面, 非藥物干預都是至關重要的。最近的指南出版物有助提高公眾 對高血壓的認識並鼓勵市民改變生活方式。

TABLE I. Classification of office blood pressure* and definitions of hypertension grades $^{3}$

\begin{tabular}{lccc}
\hline Category & $\begin{array}{c}\text { Systolic BP } \\
(\mathbf{m m ~ H g})\end{array}$ & & $\begin{array}{c}\text { Diastolic BP } \\
(\mathbf{m m ~ H g})\end{array}$ \\
\hline Optimal & $<120$ & and & $<80$ \\
Normal & $120-129$ & and/or & $80-84$ \\
\hline High normal & $130-139$ & and/or & $85-89$ \\
Grade 1 hypertension & $140-159$ & and/or & $90-99$ \\
Grade 2 hypertension & $160-179$ & and/or & $100-109$ \\
Grade 3 hypertension & $\geq 180$ & and/or & $\geq 110$ \\
Isolated systolic hypertension $\dagger$ & $\geq 140$ & and & $<90$ \\
\hline
\end{tabular}

Abbreviation: $\mathrm{BP}=$ blood pressure

* BP category is defined according to the highest level of seated clinic BP, whether systolic or diastolic. The same classification is used for all ages $\geq 16$ years

Isolated systolic hypertension is graded I, 2, or 3 according to systolic BP values in the ranges indicated. The same classification is used for all ages $\geq 16$ years

unattended office BP measurement remains unclear, but available evidence suggests that conventional office SBP readings may be at least 5 to $15 \mathrm{~mm} \mathrm{Hg}$ higher. $^{3}$

The 2017 ACC/AHA guideline's definition of hypertension is controversial. According to that new definition, about $46 \%$ of adults in the US have hypertension, as compared with about $32 \%$ under the previous definition. ${ }^{1}$ This corresponds to an increase in the number of eligible patients requiring treatment by more than 7 million in the US and more than 55 million in China. ${ }^{7}$ The potential implications for management of patients with hypertension are 
TABLE 2. Definitions of hypertension according to office, ambulatory, and home blood pressure levels

\begin{tabular}{|cccc}
\hline Category & $\begin{array}{c}\text { Systolic BP } \\
(\mathbf{m m ~ H g})\end{array}$ & $\begin{array}{c}\text { Diastolic BP } \\
\text { (mm Hg) }\end{array}$ \\
\hline Office BP* & $\geq 140$ & and/or & $\geq 90$ \\
\hline Ambulatory BP & $\geq 135$ & and/or & $\geq 85$ \\
\multicolumn{1}{|c|}{ Daytime (or awake) mean } & $\geq 120$ & and/or & $\geq 70$ \\
Night-time (or asleep) mean & $\geq 130$ & and/or & $\geq 80$ \\
\hline 24-Hour mean & $\geq 135$ & and/or & $\geq 85$ \\
\hline Home BP mean & & &
\end{tabular}

Abbreviation: $\mathrm{BP}=$ blood pressure

* Conventional office BP rather than unattended office BP

immense, both for individual patients as well society and healthcare economics. The American College of Physicians and the American Academy of Family Physicians do not agree with this new definition of hypertension. ${ }^{8}$

Other international guidelines, such as those of the World Health Organization and International Society of Hypertension, ${ }^{9}$ the Chinese Joint Committee for Guideline Revision, ${ }^{10}$ the Japanese Society of Hypertension, ${ }^{11}$ and Hypertension Canada $^{12}$ define hypertension as SBP $\geq 140 \mathrm{~mm} \mathrm{Hg}$ and/or DBP $\geq 90 \mathrm{~mm} \mathrm{Hg}$.

The HKCP concurs with the 2018 ESC/ESH guideline on BP classification, which reflects the $B P$-related cardiovascular risks and benefits of $B P$ reduction in clinical trials.

\section{Blood pressure measurement}

Both the European and American guidelines strongly emphasise accurate BP measurement and recording and consideration of readings in various settings as needed. A description detailing the steps of accurate BP measurement is provided (ie, having the patient sit quietly for 5 minutes before measurement, supporting the limb used to measure $\mathrm{BP}$, ensuring that the BP cuff is at heart level, and using the correct cuff size). Out-of-office BP measurements are recommended in patients with suspected white coat hypertension, for confirmation of the diagnosis of hypertension, and for titration of BP-lowering medication, in conjunction with telehealth counselling or clinical interventions.

Out-of-office BP measurement refers to home $\mathrm{BP}$ monitoring and ambulatory $\mathrm{BP}$ monitoring. These two methods use different BP thresholds to define high BP than office-based methods do. The 2018 ESC/ESH statement's best estimates for corresponding clinic BP, home BP monitoring, and ambulatory BP monitoring can be considered as a guide (Table 2).

Although most randomised controlled trials have used clinic BP as the reference, the HKCP acknowledges the growing body of evidence surrounding the use of home and ambulatory $B P$ monitoring in the diagnosis and monitoring of hypertension and endorses the wider use of both methods.

\section{Thresholds for initiation of antihypertensive medications}

Both the European and American guidelines adopt a risk-based approach to treatment. Screening for and management of other cardiovascular disease risk factors common in hypertensive patients is recommended. The European guideline uses the Systematic COronary Risk Evaluation system to estimate the 10-year risk of a first fatal atherosclerotic event in relation to age, sex, smoking habits, total cholesterol level, and SBP. It is based on large, representative European cohort datasets with correction factors for different first-generation immigrants to Europe. Very high risk, high risk, and moderate risk correspond to calculated 10-year Systematic COronary Risk Evaluation risk values of $\geq 10 \%, 5 \%$ to $<10 \%$, and $\geq 1 \%$ to $<5 \%$, respectively. Hypertensive patients with documented cardiovascular disease, diabetes mellitus, chronic kidney disease (stage 3-5), and very high levels of individual risk factors (including grade 3 hypertension) are automatically considered to be at high or very high risk.

The American guideline recommends using the ACC/AHA Pooled Cohort Equations to estimate the 10-year risk of atherosclerotic cardiovascular disease and to guide treatment in mild hypertension. However, the ACC/AHA Pooled Cohort Equations are validated only in the US adults aged 45 to 79 years in the absence of concurrent statin therapy. The results cannot be generalised to other age and ethnic groups, and there are no correction factors to refine the risk calculations for Asian populations.

According to the 2018 ESC/ESH guideline, patients with grade 2 and 3 hypertension should be treated with BP-lowering drug treatment and lifestyle interventions. In patents with grade 1 hypertension (BP 140-159/90-99 $\mathrm{mm} \mathrm{Hg}$ ) at high risk of cardiovascular disease or with hypertensionmediated organ damage, drug treatment should also be initiated simultaneously with lifestyle interventions. In low- to moderate-risk patients with grade 1 hypertension, BP-lowering drug treatment should be initiated after 3 to 6 months if $\mathrm{BP}$ is not controlled by lifestyle interventions alone. Drug treatment in adults with high normal BP (130-139/85-89 mm Hg) should only be considered in very high-risk situations with the presence of established cardiovascular disease, especially coronary artery disease $\left(\mathrm{Fig}^{3}\right)$. In fit, older patients with hypertension (aged $\geq 80$ years), BP-lowering 


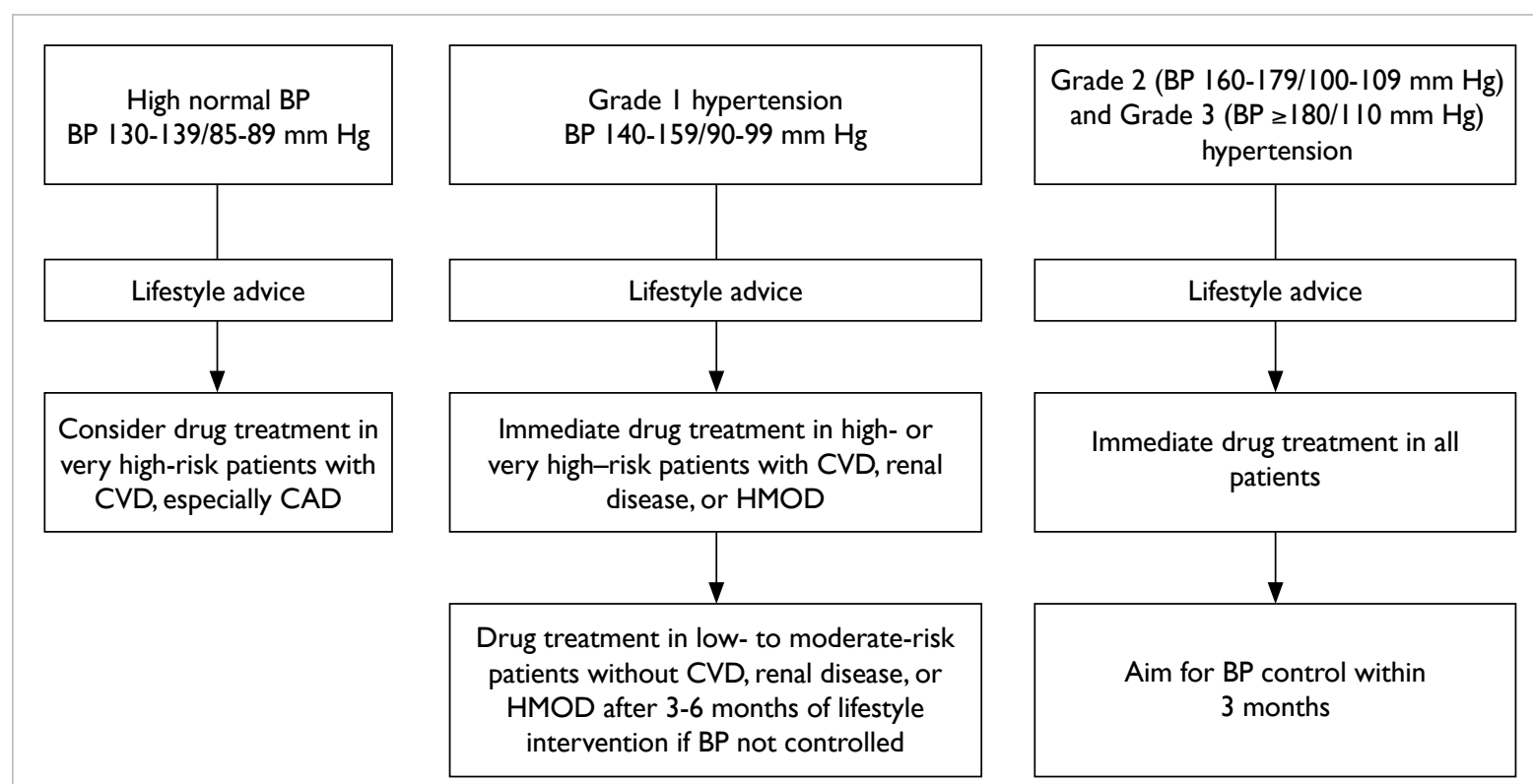

FIG. Initiation of blood pressure-lowering treatment (lifestyle changes and medication) at different initial office blood pressure levels ${ }^{3}$

Abbreviations: $\mathrm{BP}=$ blood pressure; $\mathrm{CAD}=$ coronary artery disease; $\mathrm{CVD}=$ cardiovascular disease; $\mathrm{HMOD}=$ hypertensionmediated organ damage

drug treatment and lifestyle interventions are recommended when SBP $\geq 160 \mathrm{~mm} \mathrm{Hg}$ and/or DBP $\geq 90 \mathrm{~mm} \mathrm{Hg}$.

The HKCP supports the direction of a riskbased approach to treatment decision making and echoes the 2018 ESC/ESH approach. The HKCP recommends that patients seek physicians' advice and that individualised treatment be provided after a complete assessment of the patient's clinical profile, risk factors, and preferences.

\section{Blood pressure treatment targets}

The American guideline recommends lowering BP to $<130 / 80 \mathrm{~mm} \mathrm{Hg}$ for adults, except in older patients (aged $\geq 65$ years, noninstitutionalised, ambulatory, community-living adults), in whom the target is SBP $<130 \mathrm{~mm} \mathrm{Hg}$. This one-size-fits-all BP goal raises much concern, especially for the elderly population. ${ }^{13}$ In contrast, the American College of Physicians and the American Academy of Family Physicians recommend pharmacological treatment to a target of SBP $<150 \mathrm{~mm} \mathrm{Hg}$ in adults aged $\geq 60$ years who have persistently elevated SBP $(\geq 150 \mathrm{~mm} \mathrm{Hg})$ and to a target of SBP $<140 \mathrm{~mm} \mathrm{Hg}$ in selected patients with high cardiovascular risk. ${ }^{8}$

The European guideline establishes target ranges. The first objective is to lower $\mathrm{BP}$ to $<140 / 90 \mathrm{~mm} \mathrm{Hg}$ in all patients, and provided that treatment is well tolerated, treated BP values should be targeted to $\leq 130 / 80 \mathrm{~mm} \mathrm{Hg}$ in most patients. In patients aged $<65$ years who are receiving
BP-lowering drugs, it is recommended that SBP be lowered to 120 to $129 \mathrm{~mm} \mathrm{Hg}$ in most patients. If the BP value reaches $120 / 70 \mathrm{~mm} \mathrm{Hg}$, a step-down of drug treatment should be considered, with close BP monitoring during follow-up. In older patients (aged $\geq 65$ years) and in patients with chronic kidney disease, the SBP target should be less aggressive: 130 to $139 \mathrm{~mm} \mathrm{Hg}$. A DBP target range of 70 to $79 \mathrm{~mm} \mathrm{Hg}$ is considered for all hypertensive patients, independent of risk level and co-morbidities.

The HKCP concurs with the 2018 ESC/ESH guideline in specifying target ranges for both SBP and $D B P$, with consideration of different age-groups and specific disease subgroups.

\section{Treatment strategies}

The European and American guidelines have much in common in terms of treatment strategies. ${ }^{14}$ Both recommend a similar array of non-pharmacological lifestyle interventions and drug treatments as the core strategy for BP reduction.

Non-pharmacological interventions are crucial in the prevention and management of high BP, either on their own or in combination with pharmacological therapy. These include weight reduction, hearthealthy diet, sodium reduction, physical exercise, smoking cessation, and moderation in alcohol intake.

The core drug treatment is based on four major classes: angiotensin-converting enzyme inhibitors, angiotensin receptor blockers, calcium channel blockers, and thiazide/thiazide-like diuretics. Beta 
blockers are used when there is a specific indication (eg, heart failure, angina, post myocardial infarction, or heart rate control). Both guidelines recommend the initiation of treatment in most patients with a single-pill combination containing two drugs to improve adherence and BP control. It is reasonable to use monotherapy in frail older patients and those at low risk with mild hypertension.

The HKCP assigns major importance to non-pharmacological interventions, both at the societal and individual patient levels. The HKCP sees the recent guideline publications as good opportunities to increase public awareness about hypertension and to encourage lifestyle modifications among the local population.

The HKCP agrees with the 2018 ESC/ESH guideline's drug treatment algorithm and the initiation of a two-drug combination in most patients. Monotherapy is recommended in frail older patients and those at low risk with mild hypertension.

\section{Specific considerations for geriatric patients}

Older patients are characterised by clinical heterogeneity. A multi-dimensional assessment is required to assess the biological age of each individual patient, as well as the risks and benefits of tight BP control. For patients aged 65 to 79 years with few co-morbidities who are biologically young, the target SBP should be 130 to $139 \mathrm{~mm} \mathrm{Hg}$, provided that a medication burden is acceptable. For patients aged $\geq 80$ years, or patients aged 65 to 79 years with multiple co-morbidities who are biologically old (ie, frail), the optimal BP targets are not yet defined and have to be individualised. A treatment goal of SBP of 130 to $<150 \mathrm{~mm} \mathrm{Hg}$ can be considered, as suggested by other professional societies. ${ }^{10,15}$ Careful monitoring for any adverse effects or tolerability problems associated with BP-lowering treatment is required in frail and dependent older adults. Monotherapy rather than a single-pill combination is the preferable initial pharmacotherapy according to the $2018 \mathrm{ESC} / \mathrm{ESH}$ guideline.

\section{Specific considerations for renal patients}

Patients with chronic kidney disease should be considered as having high cardiovascular risk. Adequate hypertension control is important for reducing the rate of renal function deterioration as well as cardiovascular protection. The BP targets should be tailored according to age, tolerability, and the level of proteinuria. ${ }^{16}$ For diabetic and non-diabetic patients with albumin excretion rates of $<30 \mathrm{mg}$ per 24 hours (or equivalent), the suggested $\mathrm{BP}$ target is $\leq 140 / 90 \mathrm{~mm} \mathrm{Hg}$. For diabetic and non-diabetic patients with urinary albumin excretion $\geq 30 \mathrm{mg}$ per 24 hours (or equivalent), the suggested $\mathrm{BP}$ target is $\leq 130 / 80 \mathrm{~mm} \mathrm{Hg}$. The available evidence is inconclusive but does not prove that a BP target of $<130 / 80 \mathrm{~mm} \mathrm{Hg}$ improves clinical outcomes more than a target of $<140 / 90 \mathrm{~mm} \mathrm{Hg}$ in adults with chronic kidney disease. ${ }^{16}$

\section{Specific considerations for diabetic patients}

Diabetes in combination with hypertension magnifies the risk of diabetes-related complications. Control of BP reduces the risk of microvascular (retinopathy and nephropathy) and macrovascular (especially stroke) complications. A BP goal of below $130 / 80 \mathrm{~mm} \mathrm{Hg}$ is appropriate for individuals with diabetes, particularly those with established kidney, eye, or cerebrovascular damage, provided that the medication burden is acceptable. ${ }^{17}$

The authors represent the Hong Kong College of Physicians in the following capacity:

President: Philip KT Li

Cardiology Board: KK Chan, Bryan PY Yan

Nephrology Board: SL Lui, CC Szeto

Geriatric Medicine Board: Christopher CM Lum, Francis CK Mok

Neurology Board: PW Ng, Vincent CT Mok

Endocrinology, Diabetes and Metabolism Board: KP Lau, Jenny YY Leung

Advanced Internal Medicine Board: Alice PS Kong, KL Mo

\section{Author contributions}

All authors contributed to the concept of the manuscript, acquisition of data, analysis and interpretation of data, drafting of the article and critical revision for important intellectual content. All authors had full access to the data, contributed to the study, approved the final version for publication, and take responsibility for its accuracy and integrity.

\section{Conflicts of interest}

As an editor of the journal, BPY Yan was not involved in the peer review process. Other authors have disclosed no conflicts of interest.

\section{Funding/support}

This medical practice paper received no specific grant from any funding agency in the public, commercial, or not-forprofit sectors.

\section{References}

1. Whelton PK, Carey RM, Aronow WS, et al. 2017 ACC/ AHA/AAPA/ABC/ACPM/AGS/APhA/ASH/ASPC/ NMA/PCNA Guideline for the Prevention, Detection, Evaluation, and Management of High Blood Pressure in Adults: a report of the American College of Cardiology/ American Heart Association Task Force on Clinical Practice Guidelines. J Am Coll Cardiol 2018;71:e127-248.

2. Chobanian AV, Bakris GL, Black HR, et al. Seventh report of the Joint National Committee on prevention, detection, 
evaluation, and treatment of high blood pressure. Hypertension 2003;42:1206-52.

3. Williams B, Mancia G, Spiering W, et al. 2018 ESC/ESH guidelines for the management of arterial hypertension. Eur Heart J 2018;39:3021-104.

4. Centre for Health Protection, Department of Health, Hong Kong SAR Government. Report of Population Health Survey 2014/15. Available from: https://www.chp.gov.hk/ en/static/51256.html. Accessed 14 Jan 2020.

5. Mancia G, Fagard R, Narkiewicz K, et al. 2013 ESH/ESC guidelines for the management of arterial hypertension: the Task Force for the Management of Arterial Hypertension of the European Society of Hypertension (ESH) and of the European Society of Cardiology (ESC). Eur Heart J 2013;34:2159-219.

6. SPRINT Research Group, Wright JT Jr, Williamson JD, et al. A randomized trial of intensive versus standard bloodpressure control. N Eng J Med 2015;373:2103-16.

7. Khera R, Lu Y, Lu J, et al. Impact of 2017 ACC/AHA guidelines on prevalence of hypertension and eligibility for antihypertensive treatment in United States and China: nationally representative cross sectional study. BMJ 2018;362:k2357.

8. Wilt TJ, Kansagara D, Qaseem A, Clinical Guidelines Committee of the American College of Physicians. Hypertension limbo: balancing benefits, harms and patient preferences before we lower the bar on blood pressure. Ann Intern Med 2018;168:369-70.

9. Whitworth JA, World Health Organization, International Society of Hypertension Writing Group. 2003 World Health Organization (WHO)/International Society of Hypertension (ISH) statement on management of hypertension. J Hypertens 2003;21:1983-92.

10. Joint Committee for Guideline Revision. 2018 Chinese guidelines for prevention and treatment of hypertension-a report of the Revision Committee of Chinese Guidelines for Prevention and Treatment of Hypertension. J Geriatr Cardiol 2019;16:182-245.

11. Umemura S, Arima H, Arima S, et al. The Japanese Society of Hypertension guidelines for the management of hypertension (JSH 2019). Hypertens Res 2019;42:1235481.

12. Nerenberg KA, Zarnke KB, Leung AA, et al. Hypertension Canada's 2018 guidelines for diagnosis, risk assessment, prevention and treatment of hypertension in adults and children. Can J Cardiol 2018;34:506-25.

13. Bakris G, Sorrentino M. Redefining hypertensionassessing the new blood-pressure guidelines. N Eng J Med 2018;378:497-9.

14. Whelton PK, Williams B. The 2018 European Society of Cardiology/European Society of Hypertension and 2017 American College of Cardiology/American Heart Association blood pressure guidelines: more similar than different. JAMA 2018;320:1749-50.

15. Benetos A, Bulpitt CJ, Petrovic M, et al. An expert opinion from the European Society of Hypertension-European Union Geriatric Medicine Society Working Group on management of hypertension in very old, frail subjects. Hypertension 2016;67:820-5.

16. Tang SC, Wong AK, Mak SK. Clinical practice guidelines for the provision of renal service in Hong Kong: general nephrology. Nephrology (Carlton) 2019;24 Suppl 1:9-26.

17. Garber AJ, Handelsman Y, Grunberger G, et al. Consensus statement by the American Association of Clinical Endocrinologists and American College of Endocrinology on the comprehensive type 2 diabetes management algorithm-2020 executive summary. Endocr Pract 2020;26:107-29. 